MATRA

PEMBARUAN

Jurnal Inovasi Kebijakan

jurnal.kemendagri.go.id/index.php/mp

e-ISSN: 2549-5283

p-ISSN: 2549-5151

Matra Pembaruan 3 (2) (2019): 79-88

DOI:

$10.21787 / \mathrm{mp} .3 .2 .2019 .79-88$

Keywords: Human Trafficking, Women's Trafficking, Immigration, Labor

Kata Kunci: Perdagangan Manusia, Perdagangan Perempuan, Imigrasi, Tenaga Kerja

*Korespondensi
Phone : +62 82148263025
Email : irin_ptk@ymail.com
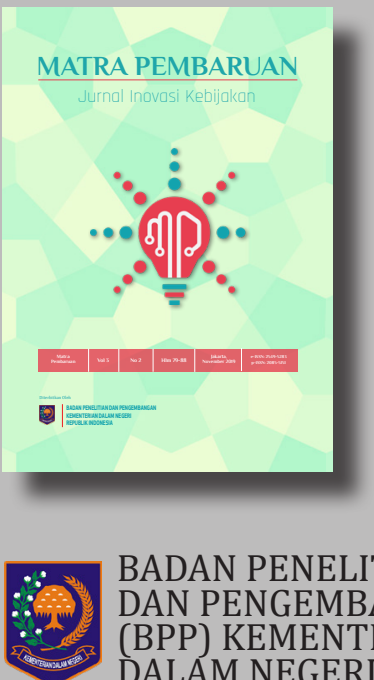

BADAN PENELITIAN DAN PENGEMBANGAN (BPP) KEMENTERIAN DALAM NEGERI

Jl. Kramat Raya No 132, Jakarta Pusat, 10450

(C) Rianawati, Wagiyem

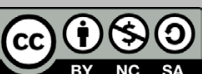

This work is licensed under the Creative Commons Attribution Non Commercial Share Alike 4.0 International License.

\section{Evaluasi Pelaksanaan Pencegahan Dan Pemberantasan Perdagangan PEREMPUAN di PERBatasan Kabupaten SAMBAS Kalimantan BARAT}

\author{
Rianawati*, Wagiyem \\ Institut Agama Islam Negeri (IAIN) Pontianak \\ Jl. Letjend Suprapto, Benua Melayu Darat, Pontianak, \\ Kalimantan Barat 78113
}

Dikirim: 18 September 2019; Direvisi: 26 Oktober 2019; Disetujui: 28 Oktober 2019

\begin{abstract}
Women's trafficking is the most classic gender issue in the course of human history. This issue often appears and as if there is virtually no solution, although various prevention and eradication efforts have been made by various parties. However, based on observations and interviews, various programs have not been explored even though many budgets have been issued. This research approach is qualitative with a descriptive method in order to describe the phenomenon occurring in the field according to the actual fact. As the source of data is the government of Sambas district, the empowerment and protection of women and children (P2TP2A, the Department of Crosssector, non-governmental organizations, and the community. Data collection techniques are in-depth interviews and documentation. This research finding are: 1) the government who participated directly and committed to TPPO (women) are the Bappeda, DP3AP2KB, Department of Labor, and immigration; 2) group participation but not committed in TPPO (women) namely, the Education Office; 3) group participation and commitment in eradication but not involved in the prevention of the trafficking of women namely the social service and the Court; 4) the party involved but not committed in the crime case of trafficking in women by police (Polres Sambas); 5) planning and implementating of prevention and eradication of women's trafficking in Sambas district are less than optimal; 6) Monitoring and evaluation of the prevention and eradication of women's trade in Sambas district are less than optimal; 6) available facilities and infrastructure related to the prevention and eradication of the trafficking of women are still insufficient and far from expectation; 7) lack of public understanding of women trafficking.
\end{abstract}

\section{Intisari}

Perdagangan perempuan merupakan persoalan gender paling klasik dalam perjalanan sejarah umat manusia. Persoalan ini kerap kali muncul dan seolah hampir tidak ada solusinya, meski berbagai upaya pencegahan dan pemberantasan telah dilakukan oleh berbagai pihak. Namun berdasarkan hasil observasi dan wawancara, berbagai program belum berjalan maksimal meskipun banyak anggaran yang telah dikeluarkan. Pendekatan penelitian ini adalah kualitatif dengan metode deskriptif dalam rangka menggambarkan fenomena yang terjadi di lapangan sesuai dengan fakta sebenarnya. Adapun yang menjadi sumber datanya ialah pihak Pemerintah Daerah Kabupaten Sambas, Dinas Pemberdayaan dan Perlindungan Perempuan dan Anak (P2TP2A, Dinas-dinas lintas sektoral, Lembaga Swadaya Masyarakat, dan Masyarakat. Teknik pengumpulan data yaitu wawancara mendalam dan dokumentasi. Sedangkan teknik analisis data yang digunakan dalam penelitian ini adalah melalui teknik analisis interaktif, (reduksi, display dan verifikasi data). Temuan riset ini yaitu: 1) pemerintah yang berpartisipasi langsung dan berkomitmen pada perdagangan perempuan adalah Bappeda, DP3AP2KB, Dinas Tenaga Kerja, dan Imigrasi; 2) kelompok partisipasi tetapi tidak berkomitmen dalam 
TPPO (perempuan) yakni, Dinas Pendidikan; 3) kelompok partisipasi dan komitmen dalam pemberantasan namun tidak terlibat dalam pencegahan perdagangan perempuan yakni Dinas Sosial dan Pengadilan; 4) pihakyang dilibatkan tetapi tidak berkomitmen dalam TPPO perempuan yakni kepolisian (Polres Sambas); 5) perencanaan dan pelaksanaan pencegahan dan pemberantasan perdagangan perempuan di Kabupaten Sambas kurang optimal; 6) pemantauan dan Evaluasi Pencegahan dan Pemberantasan Perdagangan Perempuan di kabupaten Sambas kurang optimal; 7) Sarana dan Prasarana yang tersedia terkait dengan pencegahan dan pemberantasan perdagangan perempuan masih kurang memadai dan jauh dari harapan; 8) kurangnya pemahaman masyarakat terhadap perdagangan perempuan.

\section{Pendahuluan}

Perdagangan perempuan merupakan salah satu persoalan yang kerap kali muncul dari suatu periode zaman ke zaman lainnya. Hasil penelitian (2017) menyebutkan permasalahan di perbatasan Indonesia-Malaysia yang perlu penanganan serius oleh pemerintah adalah perdagangan perempuan, seperti yang terjadi di wilayah Entikong. Tindak pidana perdagangan orang khususnya perempuan dan anak, telah meluas dalam bentuk jaringan kejahatan baik terorganisasi maupun tidak terorganisasi (Widiastuti, 2010).

Undang-Undang No 21 Tahun 2007 tentang Pemberantasan Tindak Pidana Perdagangan Orang Pasal 1 Ayat (1) menyebutkan, perdagangan orang adalah tindakan perekrutan, pengangkutan, penampungan, pengiriman, pemindahan, atau penerimaan seseorang dengan ancaman kekerasan, penggunaan kekerasan, penculikan, penyekapan, pemalsuan, penipuan, penyalahgunaan kekuasaan, atau posisi rentan, penjeratan utang atau memberi bayaran atau manfaat, sehingga memperoleh persetujuan dari orang yang memegang kendali atas orang lain tersebut, baik yang dilakukan di dalam negara maupun antar negara, untuk tujuan eksploitasi.

Persoalan ini tidak ada habisnya, kendati berbagai upaya pencegahan dan pemberantasan perdagangan perempuan telah dilakukan oleh pemerintah dan berbagai lembaga yang terkait. Perdagangan orang secara umum merujuk pada: perekrutan, transportasi, pemindahan, penempatan, ataupun penerimaan seseorang dengan ancaman atau penggunaan kekerasan, atau bentuk-bentuk paksaan lain dengan tujuan eksploitasi (Nel, 2005, p. 2). Astuti (2018) menyebutkan bahwa perdagangan perempuan dan anak yang terjadi di perbatasan Entikong Kalimantan Barat dengan tujuan pekerja gelap dan pekerja seks. Lebih lanjut, Bintari dan Djustiana (2017, pp. 130-131) menyebutkan terdapat beberapa bentuk perdagangan orang yang terjadi pada perempuan dan anak-anak di antaranya: (1) Kerja paksa seks dan eksploitasi seks; (2) Pembantu Rumah Tangga (PRT) (3)
Bentuk lain dari kerja migran; (4) Penari, penghibur, dan pertukaran budaya-terutama di luar negeri; (5) Pengantin pesanan-terutama di luar negeri. Beberapa perempuan dan anak perempuan yang bermigrasi sebagai istri dari orang berkebangsaan asing, telah ditipu dengan perkawinan; (6) Beberapa bentuk buruh/pekerja anak terutama di Indonesia; (7) Trafficking/penjualan bayi.

Upaya menuntaskan serta menutup habis masalah perdagangan perempuan memang tidak semudah membalikkan telapak tangan. Bahkan payung hukum tertinggi pemerintah melalui UU No 21 Tahun 2007 tentang Pemberantasan Tindak Pidana Perdagangan Orang (TPPO) belum maksimal dalam menekan persoalan ini. Niko (2016) menyebutkan perempuan dan anak yang rentan menjadi korban trafficking di perbatasan karena kondisi keluarga mereka yang miskin. Para calon tenaga kerja terdorong meninggalkan tempat tinggalnya untuk mencari pekerjaan di negara tetangga karena berbagai alasan. Di antaranya adalah tekanan pengangguran atau gaji rendah yang mereka terima di tempat asal, pernikahan dini, atau menjanda pada usia muda, dan tidak cukup uang untuk menghidupi anak-anaknya (Widayatun, 2008). Muflichah dan Bintoro (2009) menyebutkan, kurangnya akses pendidikan bagi perempuan dan iming-iming mendapatkan kerja layak menjadi rentetan penyebab terjadinya trafficking.

Oleh sebab itu, dalam menyikapi persoalan keamanan sudah semetinya perbatasan perlu diperkuat pijakannya. Pijakan yang dimaksudkan adalah pijakan hukum, pijakan pembangunan sosial dan ekonomi, serta pijakan pembangunan institusi. Dalam rangka mewujudkan perbatasan sebagai halaman depan negara, maka sudah semestinya pembangunan kawasan perbatasan harus ditingkatkan dengan cara memperkuat kapasitas aparat melibatkan pihak swasta dan pentingnya untuk melibatkan masyarakat. Data Badan Nasional Penempatan dan Perlindungan Tenaga Kerja Indonesia (BNP2TKI) di Kalimantan Barat menyatakan, Kabupaten Sambas merupakan kabupaten di Kalimantan Barat penyumbang masalah perdagangan manusia tertinggi. Hal ini dibuktikan dengan adanya 371 orang, yang terdiri dari 322 laki-laki, 38 perempuan dan 11 anak-anak menjadi korban perdagangan manusia (BNP2TKI Kalbar, 2017).

Darwinsyah (2011) menyebutkan, di antara wilayah Indonesia yang paling rentan dalam masalah perdagangan perempuan dan anak adalah wilayah Indonesia yang berbatasan langsung dengan Malaysia khususnya daerah Kalimantan Barat. Senada dengan pendapat Elyta (2012) yang menyebutkan, perempuan di perbatasan sangat rentan menjadi korban human trafficking ke Malaysia.

Irawan (2014) mengungkapkan, terdapat 
kolaborasi antara peran aktor negara dan aktor non negara dalam mewujudkan berbagai kepentingan, termasuk di dalamnya adalah mewujudkan keamanan bagi masyarakat di perbatasan negara. Hal ini berarti, setiap aktor pemerintahan dan non pemerintahan bersama-sama dalam menuntaskan kejahatan perdagangan orang yang sudah pada taraf internasional ini.

Pada dasarnya ketimpangan antar wilayah perbatasan dengan wilayah lainnya di Kalimantan Barat terlihat pada sektor ekonomi. Di mana wilayah perbatasan masih tertinggal dan terbelakang. Keterbelakangan masyarkaat pedesaan menurut Niko (2019) ditandai dengan masih tingginya angka kemiskinan dan tingginya angka buta huruf. Pendapat Asyahri dan Syafril (2018) mengatakan bahwa prioritas pemerataan pembangunan dapat mendorong potensi ekonomi serta mengurangi ketimpangan regional antardaerah. Perbatasan menjadi salah satu indikator kuat atau lemahnya suatu negara (Grevisanto, 2016). Oleh sebab itu pengelolalah perbatasan perlu ditinggkatkan terutama dalam hal keamanan. Hal demikian dikarenakan daerah perbatasan merupakan entitas politik ruang dan juga menjadi garis penghubung kedaulatan sebuah negara terkait dengan pembangunan sosial ekonomi perbatasan. Sebagai penghubung kedaulatan negara daerah perbatasan menjadi tempat yang rentan terhadap kejahatan-kejahatan lintas batas negara seperti penyelundupan illegal logging, penyelundupan gula dan juga penyelundupan manusia (human trafficking).

Daerah perbatasan seperti menjadi sasaran empuk bagi para pelaku kejahatan penyeludupan lintas batas, hal ini disebabkan karena letaknya yang sangat mudah dijangkau. Pelanggaran perdagangan lintas batas ini sudah semestinya memerlukan perhatian yang khusus guna menjaga kedaulatan perbatasan. Pada perbatasan negara di Kabupaten Sambas, memiliki aparat-aparat keamanan yang lengkap seperti Kepolisian, Imigrasi, dan Bea Cukai. Akan tetapi pelanggaran perdagangan lintas batas penyeludupan tidak hanya melebar di bidang ekonomi namun keamanan manusia juga akan terancam (Kristi, Damayanti, \& Haqqi, 2018).

Berbicara mengenai isu keamanan yang berkaitan dengan keamanan manusia (human security), UNDP menyebutkan, keamanan manusia (human security) berarti tidak terlepas dari penderitaan kronik yang bisa disebabkan oleh adanya kelaparan, penyakit, dan penindasan (Laki, 2006). Selain tiga poin tersebut, tidak adanya kepastian hukum yang diberikan oleh negara terhadap masyarakat menunjukkan negara tersebut sedang berada dalam kondisi yang tidak aman. Artinya, adanya situasi perdagangan perempuan di Kabupaten Sambas menunjukkan keamanan manusia di perbatasan masih perlu ditingkatkan.
Pemerintah daerah merespons trafficking dengan menerbitkan Peraturan Gubernur Kalimantan Barat No 25 Tahun 2017, yang dirumuskan dalam Rencana Aksi Daerah Penghapusan Perdagangan Orang (trafficking) Terutama terhadap Perempuan dan Anak. Rencana aksi tersebut dilaksanakan secara terpadu, sistematis, komprehensif dan berkesinambungan. Belajar dari berbagai permasalahan yang mengemuka ini dalam konteks hukum, keamanan, dan pertahanan kawasan perbatasan menunjukkan, tidak dapat dikesampingkan sebagai tolok ukur upaya mengembangkan pembangunan di kawasan perbatasan strategis (Nasution, 2018).

Tulisan ini mencoba memberikan penjelasan yang lebih memadai dan urgensi pelaksanaan dan evaluasi terhadap pencegahan dan pemberantasan perdagangan orang khususnya perempuan dan anak di wilayah Kabupaten Sambas. Hal ini berkaitan pula untuk mengetahui sejauh mana kinerja pemerintahan, baik pada tingkat kabupaten, kecamatan maupun desa dalam memahami pencegahan perdagangan manusia. Artinya dengan adanya evaluasi, maka kedepannya diharapkan pelaksanaan pencegahan dan pemberantasan trafficking di Kabupaten Sambas dapat lebih baik.

Penelitian evaluasi kebijakan menurut Jones (2007, p. 199) adalah aktivitas yang dirancang untuk menilai atau mengukur manfaat dari suatu kebijakan atau program-program pemerintah yang dilaksanakan melalui sub-sub kebijakan yang lebih spesifik. Kemudian, perlu juga diketahui bagaimana partisipasi masyarakat terhadap tindak pencegahan dan pemberantasan perdagangan perempuan di kabupaten Sambas. Ditegaskan Wulang, Nawawi, dan Nurlinah (2013, pp. 5-6) dan Minin (2011, pp. 27-28), korban trafficking berhak memperoleh rehabilitasi dan restitusi. Dari temuan penelitian ini diharapkan akan dikembangkan konsep dan desain baru untuk penanganan, pencegahan dan pemberantasan perdagangan orang khususnya perempuan di kabupaten Sambas. Hal ini sesuai dengan pedoman Trafficking Victims Protection Act (TVPA) tahun 2000 (Judge \& Boursaw, 2016).

\section{Metode}

Penelitian ini menggunakan jenis pendekatan deskriptif eksploratif yang mana sumber data berasal dari data primer dan data sekunder. Istilah "deskriptif" berasal dari istilah bahasa Inggris to describe yang berarti memaparkan atau menggambarakan sesuatu hal. Creswell (2014) menyebutkan data penelitian kualitatif dapat berupa lisan dan tulisan. Data primer didapatkan melalui wawancara dan pendapat aktor. Informan dalam penelitian ini yaitu pejabat di BNP2TKI Kalimantan Barat dan Dinas Ketenagakerjaan Kabupaten Sambas. Wawancara dilakukan dengan 
cara bertatap muka dengan informan untuk mendapatkan penjelasan mengenai urgensi dan keparahan kasus perdagangan perempuan dan anak di Kalimantan Barat secara umum dan Kabupaten Sambas secara khusus. Data sekunder dalam penelitian ini didapatkan melalui penelusuran tulisan-tulisan ilmiah seperti jurnal dan buku yang terkait dengan tema penelitian. Selain buku dan jurnal ilmiah, data sekunder juga berasal dari Dinas Sosial Kabupaten Sambas, Bappeda Kabupaten Sambas, Dinas Ketenagakerjaan Kabupaten Sambas, Dinas Pemberdayaan dan Perlindungan Perempuan dan Anak (P2TP2A) Kabupaten Sambas, Dinas Pendidikan Kabupaten Sambas, BNP2TKI Provinsi Kalimantan Barat dan Dinas Pemberdayaan dan Perlindungan Perempuan dan Anak (P2TP2A) Provinsi Kalimantan Barat.

\section{Hasil dan Pembahasan}

Pada bagian ini akan memaparkan beberapa poin terkait; komitmen pemerintah dalam pelaksanaan pencegahan dan pemberantasan perdagangan perempuan; perencanaan dan pelaksanaan pencegahan dan pemberantasan perdagangan perempuan di Kabupaten Sambas; pemantauan dan evaluasi pencegahan dan pemberantasan perdagangan perempuan di Kabupaten Sambas; dukungan sarana dan prasarana pencegahan dan pemberantasan perdagangan perempuan di Kabupaten Sambas; serta pengetahuan dan partisipasi masyarakat terkait tindak pencegahan dan pemberantasan perdagangan perempuan di Kabupaten Sambas. Beberapa poin di atas menjadi fokus penelitian ini dan terangkum pada bagian pembahasan.

\section{A. Komitmen Pemerintah dalam Pemberantasan Perdagangan Perempuan}

Berdasarkan paparan data hasil wawancara dengan informan dapat diketahui, beberapa instansi yang terlibat dalam program pencegahan dan pemberantasan perempuan yaitu: Pertama, Dinas P2TP2A selaku leading sector dalam pencegahan dan pemberantasan perdagangan perempuan telah berpartisipasi dan berkomitmen dalam mencegah terjadinya perdagangan perempuan. Terdapat beberapa wujud kegiatan yang dilakukan oleh dinas tersebut berdasarkan hasil wawancara dan rekaman data kegiatan meliputi: (a) Sosialisasi terkait dampak atau bahaya TPPO (tindak pidana perdagangan orang), (b) Sosialisasi bidang hukum terkait TPPO dengan melibatkan instansi terkait (kepolisian), (c) Memberikan pelatihan keterampilan terhadap perempuan usia produktif, (d) Membentuk satgas di tingkat Desa, (e) Melakukan pemetaan terkait faktor penyebab terjadinya perdagangan perempuan, (f) Menyusun Rencana Strategis (Renstra) yang memuat poin penanganan perdagangan perempuan, (g) Pembinaan upaya pencegahan perdagangan perempuan.

Terkait dengan pemberantasan, Dinas P2TP2A melakukan beberapa kegiatan meliputi: (a) Membentuk pos pengaduan baik di tingkat kabupaten yang tempatnya di kantor Dinas P2TP2A dan di tingkat desa dengan memanfaatkan kantor desa sebagai pos pengaduan bagi masyarakat yang ingin melaporkan kasus korban perdagangan perempuan, (b) Mengeluarkan rujukan bagi korban untuk dialihkan kepada pihak yang berwenang, dan (c) Melakukan pemetaan terkait perkembangan kasus perdagangan perempuan dari tahun ke tahun.

Berdasarkan rencana strategis tahun 20132018 DP3A Provinsi Kalimantan Barat, 2013:2728 serta rencana kerja tahun anggaran 2015 (DP3A Provinsi Kalimantan Barat, 2014:17-18), fungsi Sub Bidang Penghapusan Trafficking dan Tindak Kekerasan memiliki beberapa fungsi yang dapat juga dijadikan rujukan oleh DP3AP2KB Kabupaten Sambas terkait dengan pelaksanaan dan pencegahan perdagangan perempuan sebagai berikut; (a) Penyusunan program, (b) Pengumpulan, pengolahan dan perumusan bahan kebijakan daerah, (c) Pengawasan pelaksanaan tugas dan fungsi staf, (d) Koordinasi dan fasilitas tugas pokok dan fungsi, (e) Pemberian dukungan penyelenggaraan, (f) Penyelenggaraan pemerintah dan pelayanan umum, (g) Pembinaan dan pengawasan, (h) Penyusunan konsep saran dan pertimbangan, (i) Monitoring, evaluasi dan pelaporan, (j) Pelaksanaan tugas lain yang diberikan.

Kedua, Dinas Tenaga Kerja Kabupaten Sambas, selain DP3AP2KB, yang berpartisipasi dalam upaya pencegahan dan pemberantasan perdagangan perempuan ialah Dinas Tenaga Kerja. Beberapa kegiatan yang diupayakan oleh instansi tersebut. Adapun kebijakan dalam kategori umum meliputi; (a) Pembentukan Satuan Petugas (Satgas) perlindungan pekerja dalam negeri dan luar negeri, (b) Pembentukan Layanan Terpadu Satu Atap (LTSA) guna memudahkan pelayanan bagi calon pekerja, (c) Pembentukan Desa Imigrasi Produktif (desmigratif) sebagai upaya pemutusan mata rantai tenaga kerja luar negeri.

Adapun kebijakan khusus yang dilaksanakan oleh instansi ini yang dilaksanakan di LTSA meliputi; (a) Pembatasan usia, usia minimal 18 tahun untuk bisa mengurus dokumen resmi, (b) Surat izin keluarga, bagi yang sudah menikah, bagi yang belum menikah harus membawa surat ijin dari orang tua, pada saat pengurusan dokumen juga harus didampingi suami atau orang tua langsung, (c) Medical check up, upaya ini dilakukan untuk memastikan bahwa calon tenaga kerja tidak mengalami gangguan kesehatan dan tidak dalam keadaan hamil, dan (d) Mensosialisasikan aplikasi android kepada masyarakat seperti aplikasi PAP, 
Save travel dan jendela TKI.

Terkait dengan pemberantasan perdagangan orang (perempuan dan anak), tugas Dinas Tenaga Kerja Kabupaten Sambas hanya sebatas menerima pengaduan dari masyarakat dan mendalami pengaduan, selanjutnya memetakan rujukan bagi korban apakah akan dilimpahkan kepada kepolisian jika terdapat unsur kriminalnya, atau dilimpahkan ke Dinas Pemberdayaan Perempuan dan Perlindungan Anak (DP3A) Provinsi jika memerlukan pendampingan.

Ketiga, Keimigrasian Kabupaten Sambas. Salah satu instansi yang terlibat dalam upaya pencegahan dan pemberantasan perdagangan perempuan di Kabupaten Sambas ialah Imigrasi. Dalam pencegahan, Imigrasi melakukan deteksi dini terhadap calon pekerja luar negeri dengan melakukan wawancara dan pengecekan keabsahan data. Selain itu, Imigrasi juga melakukan sosialisasi kepada masyarakat baik atas inisiatif Imigrasi ataupun diundang oleh instansi lainnya sebagai pemateri. Keempat, Dinas Pendidikan Kabupaten Sambas salah satu upaya yang dilakukan oleh Dinas Pendidikan ialah dengan melakukan sosialisasi kepada masyarakat agar lebih meningkatkan taraf pendidikan karena kebanyakan yang menjadi korban perdagangan perempuan ialah perempuan dari kalangan kurang mampu dengan taraf pendidikan yang rendah. Adapun dalam pemberantasan perdagangan perempuan, Dinas pendidikan tidak terlibat karena di luar tugas dan fungsinya.

Kelima, Dinas Sosial Kabupaten Sambas. Dalam upaya pencegahan perdagangan perempuan, Dinas Sosial tidak melakukan kegiatan, namun dilibatkan berpartisipasi dalam melakukan sosialisasi oleh Dinas Pemberdayaan Perempuan atau Dinas Tenaga Kerja dan Transmigrasi. Adapun dalam upaya pemberantasan, Dinas Sosial bertugas dalam pemulangan korban. Selanjutnya jika terdapat unsur kriminal akan dilimpahkan kepada pihak Kepolisian. Keenam, Pengadilan Negeri Sambas. Dalam upaya pencegahan perdagangan perempuan di Kabupaten Sambas, pihak Pengadilan Negeri tidak berpartisipasi dan tidak pula memberikan komitemen, hal ini dikarenakan tugas dan fungsi pengadilan itu sendiri. Adapun dalam pemberantasan perdagangan perempuan, tugas pengadilan ialah, Pengadilan wajib menerima, memeriksa dan memutuskan perkara.

Ketujuh, Polrestabes Sambas. Kepolisian tidak melaksanakan kegiatan terkait upaya pencegahan perdagangan perempuan, namun ada kalanya diundang atau dilibatkan oleh dinas pemberdayaan perempuan atau dinas tenaga kerja dan transmigrasi dalam sosialisasi atau penyuluhan bidang hukum. Dalam pemberantasan perdagangan perempuan, Polrestabes Satuan Resort Kriminal Unit Perlindungan Perempuan dan Anak termasuk dalam anggota satgas yang bertugas dalam penegakan hukum.

Kedelapan, Badan Perencanaan Pembangunan Daerah (Bappeda) Kabupaten Sambas. Bappeda tidak terlibat secara langsung dalam upaya pencegahan dan pemberantasan perdagangan perempuan di Kabupaten Sambas, namun pernah dilibatkan dalam sosialisasi oleh Dinas Pemberdayaan Perempuan atau Dinas Tenaga Kerja dan Transmigrasi sebagai pemateri. Tidak terlibatnya Bappeda Kabupaten Sambas dalam upaya tersebut dikarenakan tugas dan fungsinya tidak termasuk dalam pelaksana teknis. Dalam hal ini tugas Bappeda adalah memastikan kesesuaian antara rencana anggaran yang diajukan masingmasing intansi dengan kegiatan yang dilakukan di lapangan.

\section{B. Pencegahan Pemberantasan Perdagangan Perempuan di Kabupaten Sambas}

Sepertiyangkita ketahui, agenda pembangunan kawasan perbatasan darat terdiri dari aspek infrastruktur kawasan perbatasan, aspek penataan ruang kawasan perbatasan, peningkatan komoditas unggulan daerah dan ekonomi kerakyatan yang berdaya saing di kawasan perbatasan darat. Aspek pelayanan sosial dasar kawasan perbatasan, dalam hal ini belum terdapat agenda penting yang memasukkan keamanan manusia sebagai hal yang mendesak. Temuan penelitian ini menunjukkan, human security sudah seharusnya menjadi agenda utama dalam pembangunan kesadaran masyakarat di perbatasan, dalam rangka pencegahan human trafficking.

Keberadaan General Border Committee (GBC) di perbatasan darat, yang mana GBC merupakan satu-satunya lembaga atau badan komisi kerja sama bilateral antara pemerintah Indonesia dengan Malaysia yang menangani masalah pengelolaan dan penyelesaian isu-isu seputar perbatasan. Meski demikian, tidak serta merta kemananan manusia (human security) menjadi kewajiban dan tugas dari agenda kerja GBC, melainkan human security masyarakat perbatasan menjadi tanggung jawab kita bersama sebagai bangsa Indonesia. Adapun perencanaan dan pelaksanaan dalam upaya pemerintah daerah ikut dalam pemberantasan perdagangan perempuan di Kabupaten Sambas, sebagai berikut:

\section{1) Payung Hukum}

Terkait dengan perencanaan, DP3AP2KB Kabupaten Sambas telah menyusun Rencana Strategis (Renstra) yang memuat pencegahan dan pemberantasan perdagangan perempuan atau di dalam renstra disebut dengan TPPO. Masing-masing instansi pemerintah daerah Kabupaten Sambas telah memiliki Renstra dan Rencana Kerja (Renja) 
periode 2016-2021. Peraturan yang dijadikan payung hukum oleh pemerintah Kabupaten Sambas dalam upaya pencegahan dan pemberantasan perdagangan perempuan ialah UU No 21 Tahun 2007 Tentang Pemberantasan Tindak Pidana Perdagangan Orang (TPPO).

Payung hukum yang kedua ialah Peraturan Daerah No 3 Tahun 2015 Tentang Pencegahan dan Penanganan Korban Perdagangan Orang. Landasan atau payung hukum yang ketiga ialah Peraturan Bupati No 6 Tahun 2017 Tentang Gugus Tugas P2TP2A dan RAD Pencegahan dan Penanganan Perdagangan Orang.

\section{2) Petunjuk Teknis}

Petunjuk teknis merupakan acuan atau petunjuk kerja agar pekerjaan lebih terarah sehingga tujuan dapat dicapai dengan maksimal. Dalam kasus pencegahan dan pemberantasan perdagangan perempuan di Kabupaten Sambas, petunjuk teknisnya berupa SOP. Petunjuk pencegahan dan penangan korban perdagangan perempuan di Kabupaten Sambas adalah Peraturan Bupati No 5 Tentang SOP Penanganan Korban Perdagangan Orang dan Tindak Kekerasan.

Terkait Peraturan, Peraturan yang menjadi payung hukum pemberantasan perdagangan perempuan di Kabupaten Sambas yaitu: (a) UU TPPO No 21 Tahun 2007; (b) Perda Provinsi Kalimantan Barat No 3 Tahun 2015 Tentang Pencegahan dan Penanganan Korban Perdagangan Orang; (c) Perbup No 6 Tahun 2017 Tentang Gugus Tugas P2TP2A dan RAD Pencegahan dan Penanganan Perdagangan Orang. Artinya, komitmen pemerintah sangat tinggi dalam pemberantasan perdagangan perempuan anak di Kabupaten Sambas.

Sementara itu, pemda dan stakeholder terkait yang bekerja sama dan berkoordinasi dalam pelaksanaan perda TPPO yaitu Dinas P3AP2 Kabupaten Sambas, Bappeda, Dinas Tenaga Kerja dan Transmigrasi Kabupaten Sambas serta Imigrasi sudah baik dalam koordinasi. Namun, disisi lain penyediaan sarana dan prasarana terkait dengan pencegahan dan pemberantasan perdagangan perempuan masih tidak memadai seperti belum adanya kantor sekretariat khusus penanganan TPPO di tingkat kabupaten dan kecamatan, tidak adanya shelter dan psikolog khusus di kabupaten dan kecamatan. Hal ini menunjukkan, adanya komitmen pemerintah daerah yang tinggi tidak dibarengi dengan penyediaan sarana prasarana dalam penanggulangan dan pemberantasan perdagangan orang di Kabupaten Sambas secara umum.

Kemudian, tata laksana Perbup No 6 Tahun 2017 Tentang Gugus Tugas P2TP2A dan RAD Pencegahan dan Penanganan Perdagangan Orang masih belum secara maksimal. Masih lemahnya human security masyarakat yang tinggal di wilayah perbatasan perlu mendapat perhatian khusus, sebab adanya mobilitas tinggi dari Kabupaten Sambas ke Malaysia yang membuka akses besar bagi perdagangan orang secara besar-besaran. Sehingga, tidak hanya koordinasi antar dinas dan lembaga terkait yang harus dilibatkan, tetapi juga warga lokal harus dilibatkan secara langsung.

\section{Pemantauan dan Evaluasi Pencegahan dan Pemberantasan Perdagangan Perempuan di Kabupaten Sambas}

Berdasarkan data hasil wawancara dengan informan dapat diketahui, pemantauan dilakukan secara intens terkait dengan pemberantasan atau penanganan korban perdagangan perempuan di kabupaten Sambas oleh berbagai instansi yang terkait baik dari pos pengaduan yang diprakarsai DP3AP2KB dan Disnaker Sambas, maupun oleh pihak penegak hukum dalam hal ini oleh Polres maupun Pengadilan Negeri Sambas. Pemantauan tersebut dilakukan oleh bupati kepada instansi terkait maupun oleh kepala dinas terhadap petugas yang bertanggung jawab. Artinya pemantauan dari pihak pemerintah daerah Kabupaten Sambas sudah mengusahakan pencegahan dan terlibat langsung dalam penanganan dan pencegahan perdagangan orang.

Terkait dengan upaya pencegahan perdagangan perempuan yang terdiri dari kegiatan sosialisasi dan pelatihan keterampilan kepada masyarakat hanya beberapa kegiatan yang dipantau oleh pejabat berwenang. Hal ini disebabkan banyaknya kegiatan sosialisasi dan pelatihan keterampilan yang dilakukan berbenturan dengan kegiatan yang diikuti oleh atasan sehingga terdapat beberapa kegiatan terkait dengan upaya pencegahan perdagangan perempuan yang tidak terpantau. Pada Badan Perencanaan Pembangunan Daerah kabupaten Sambas, yang melakukan pemantauan ialah Bupati langsung, sedangkan Polres Sambas yang melakukan pemantauan kegiatan/program saja. Berdasarkan informasi dari masyarakat kecamatan Paloh dan Sajingan Besar, diketahui, belum pernah ada sosialisasi yang dan pemantauan oleh dinas-dinas terkait dalam rangka pencegahan dan pemberantasan perdagangan orang.

Setelah melalui pelaksanaan, maka tahap selanjutnya adalah evaluasi. Evaluasi dapat juga diartikan sebagai proses menilai sesuatu berdasarkan kriteria atau tujuan yang telah ditetapkan yang selanjutnya diikuti dengan pengambilan keputusan atas obyek yang dievaluasi.

Evaluasi kegiatan terkait dengan pencegahan dan pemberantasan perdagangan perempuan di Kabupaten Sambas tidak dilakukan per-kegiatan melainkan dilakukan atas dasar laporan tahunan atau laporan semester yang disampaikan oleh bawahan terhadap atasan. Dalam alur laporan 
dan evaluasi ini adalah seluruh Kepala Seksi menyampaikan laporan kepada Kepala Bidang. Kepala Bidang mengevaluasi kinerja Kepala Seksi, Kepala Bidang menyampaikan laporan kepada Kepala Dinas atau Kepala Badan. Kemudian Kepala Dinas atau Kepala Badan mengevaluasi kinerja Kepala Bidang. Kemudian Kepala Dinas menyampaikan laporan kepada Bupati dan Bupati mengevaluasi masing-masing kinerja Kepala Dinas.

Khusus kepolisian dalam hal ini Polres Sambas menyampaikan laporan langsung kepada Kapolda dan laporannya tidak hanya berupa laporan tahunan atau semester melainkan juga laporan bulanan, baik laporan terkait dengan perdagangan perempuan maupun laporan kasus-kasus lain yang ditangani oleh Polres Sambas. Sama halnya dengan pemantauan, evaluasi oleh pihak kabupaten belum pernah dilakukan terhadap kecamatan Paloh dan Sajingan Besar terkait dengan pencegahan dan pemberantasan perdagangan perempuan. Begitu juga pihak kecamatan belum pernah melakukan evaluasi terhadap Desa Sebubus dan Desa Sebungan terkait program atau kegiatan pencegahan dan pemberantasan perdagangan perempuan.

\section{Dukungan Sarana dan Prasarana Pencegahan dan Pemberantasan Perdagangan Perempuan di Kabupaten Sambas}

Sarana dan prasarana merupakan berbagai benda dan program pembangunan yang dapat digunakan sebagai alat untuk mencapai tujuan. Guna mencapai angka pencapaian pencegahan dan pemberantasan perdagangan perempuan yang tinggi diperlukan sarana dan prasarana yang memadai di masing-masing instansi yang ada di Kabupaten Sambas. Salah satu sarana prasarana yang menjadi terobosan besar pemerintah daerah kabupaten Sambas adalah adanya Layanan Terpadu Satu Atap (LTSA) yang berisikan perwakilan dari seluruh dinas dan instansi lain yang terlibat dalam upaya pencegahan dan pemberantasan perdagangan perempuan.

Tujuan dibentuknya LTSA adalah untuk menekan jumlah pekerja non-prosedural karena cukup dengan mendatangi pusat layanan ini, masyarakat dapat mengurus segala administrasi terkait persayaratan untuk menjadi pekerja prosedural di luar negeri. Selain itu, layanan ini memang dikhususkan bagi calon tenaga kerja saja. Adapun untuk keperluan administrasi umum lainnya masyarakat harus datang ke kantor utama.

Sarana prasarana lainnya yang ada ialah fasilitas kantor pada umumnya seperti laptop, printer, jaringan internet, gedung, meja dan kursi yang tersedia di kantor masing-masing instansi. Untuk kendaraan dinas masih memanfaatkan kendaraan dinas umum karena belum ada kendaraan dinas khusus pencegahan dan pemberantasan perdagangan perempuan. Berdasarkan informasi dari salah satu aparat kepolisian wilayah Kabupaten Sambas, untuk kendaraan operasional di satuan reserse kriminal belum tersedia sehingga aparat menggunakan kendaraan pribadi dalam mendalami kasus perdagangan perempuan. Artinya, sarana dan prasarana belum mendukung dalam pekerjaan aparat setempat dalam penanganan TPPO. Sarana prasarana yang tidak kalah penting ialah media Komunikasi, Informasi dan Edukasi (KIE). Tujuan adanya media KIE adalah untuk memberikan informasi kepada masyarakat terkait informasi perdagangan perempuan seperti definisi perdagangan perempuan yang terintegrasi dalam definisi TPPO, bahaya atau dampak buruk dari praktik perdagangan perempuan.

Kemudian, upaya-upaya yang dapat ditempuh oleh korban perdagangan perempuan, modusmodus yang dijanjikan oleh oknum penyalur nakal dan berbagai informasi terkait lainnya. Beberapa media KIE yang tersedia bagi masyarakat seperti banner yang berisi pesan atau anjuran untuk menghindari TPPO, selain itu ada juga selebaran yang dibagikan kepada masyarakat berupa pamphlet dan booklet yang berisi informasi penting terkait TPPO.

\section{E. Pengetahuan dan Partisipasi Masyarakat terkait Tindak Pencegahan dan Pemberantasan Perdagangan Perempuan di Kabupaten Sambas}

Pada umumnya kawasan perbatasan sangat diidentikkan dengan kawasan yang terbelakang, kawasan yang tertinggal dibandingkan dengan daerah lain. Padahal potensi sumber daya alam terbilang cukup besar, kekayaan sosial budaya masyarakat juga sangat tinggi. Namun, hingga kini potensi tersebut sebagian besar tidak dapat dijadikan peluang untuk mengangkat harkat, martabat dan derajat masyarakat perbatasan dengan peningkatan ekonomi.

Oleh karena itu, perlu adanya penanganan serius terkait pembangunan kawasan perbatasan, utamanya adalah penanganan serius persoalan human trafficking di perbatasan. Dengan memperhatikan arah kebijakan dan strategi pengelolaan batas wilayah negara dan kawasan perbatasan hingga saat ini, maka satu di antara agenda penting adalah human security masyarakat di perbatasan. Artinya, pemberantasan perdagangan orang hingga ke akar-akarnya.

Berdasarkan hasil wawancara dengan masyarakat dan tokoh masyarakat di perbatasan Paloh, masyarakat setempat belum ada yang mengetahui secara pasti definisi dan pengertian perdagangan perempuan. Sumarni selaku tokoh agama di Desa Sebubus Kecamatan Paloh 
menyebutkan, pernah mendengar atau membaca definisi dari pada pengertian perdagangan perempuan atau TPPO. Demikian halnya juga dengan V.G. Yean, selaku tokoh agama di desa Sebunga, perbatasan Kecamatan Sajingan Besar juga tidak memahami pengertian teoritis perdagangan perempuan. Tidak hanya pengertiannya saja yang tidak dipahami oleh tokoh dan masyarakat yang peneliti temui melainkan dasar atau payung hukumnya juga tidak mereka pahami sama sekali. Meskipun para tokoh agama ini tidak paham mengenai pengertian perdagangan perempuan, namun keduanya tahu persis modus yang ditawarkan para oknum pelakunya yakni dengan menawarkan pekerjaan yang ringan dengan gaji yang besar.

Masyarakat seperti Sumarni (45 Tahun) yang adiknya menjadi tenaga kerja di luar negeri dan Tohirin (37) yang istrinya nasibnya sama dengan adik Sumarni menjadi tenaga kerja di luar negeri, sebenarnya merasa sangat berat melepaskan anggota keluarganya menjadi tenaga kerja di luar negeri. Namun demikian tetap harus diterima sebab himpitan ekonomi dan sempitnya lapangan kerja mengharuskan mereka merelakan anggota keluarganya untuk menjadi buruh di negeri orang. Yang terpenting adalah tetap tersampaikannya kabar dari anggota keluarga yang menjadi pekerja, cukup memberikan ketenangan terhadap keluarga yang ditinggalkan. Sebab dengan demikian sudah jelas, anggota keluarga yang bekerja keadaanya baik-baik saja.

Kemudian, keterlibatan lembaga swadaya masyarakat turut terlibat dan berperan aktif dalam pemberantasan TPPO. Wahana Visi Indonesia (WVI) merupakan salah satu LSM yang ada di Kabupaten Sambas. Bentuk komitmen yang dilakukan dalam rangka pencegahan perdagangan perempuan adalah LSM sebenarnya lebih cenderung pada perlindungan anak. Namun demikian, memang ada kaitannya dengan pemberdayaan perempuan, yang merupakan orang tua yang sangat dekat dengan anak. Peran WVI lebih fokus pada penguatan koordinasi lintas sektor yang terkait dengan perlindungan anak dan pemberdayaan perempuan.

Hal ini berarti erat kaitannya dengan peran LSM WVI sebagai aktor non negara dalam mewujudkan keamanan manusia di wilayah perbatasan, yang mana LSM ini dapat memainkan peran sebagai pihak-pihak yang tidak berkepentingan dalam rangka mewujudkan human security.

\section{KESIMPULAN}

Berdasarkan hasil penelitian didapatkan beberapa kekurangan dalam pencegahan dan pemberantasan perdagangan perempuan di Kabupaten Sambas. Oleh sebab itu peneliti menyampaikan beberapa poin masukan guna perbaikan upaya pencegahan dan pemberantasan perdagangan perempuan diantaranya: Perlunya peningkatan partisipasi dan komitmen lintas sektor, baik dalam upaya pencegahan maupun upaya pemberantasan perdagangan perempuan agar pelaksanaannya lebih massif dengan tujuan untuk menekan angka korban perdagangan perempuan di Kabupaten Sambas. Kemudian perlunya pertemuan rutin terjadwal tingkat kabupaten, kecamatan dan desa guna membahas perencanaan dan pelaksanaan pencegahan dan pemberantasan perdagangan perempuan guna menghindari ego sektoral.

Selanjutnya perlu ditingkatkan pemantauan kegiatan pencegahan dan pemberantasan perdagangan perempuan agar tiap lini dapat melaksanakan program terkait dengan pencegahan dan pemberantasan perdagangan perempuan khususnya di tingkat desa dan kecamatan. Perencanaan anggaran dan kegiatan untuk memberantas perdagangan perempuan, baik ditingkat kabupaten, kecamatan maupun ditingkat desa juga hal yang mutlak. Selain itu, sarana dan prasarana yang belum terpenuhi perlu segera dipenuhi (shelter, pos pengaduan, kendaraan, dll) agar pelaksanaan pencegahan dan pemberantasan perdagangan perempuan dapat berjalan sebagaimana yang diharapkan.

Saran lainnya adalah sosialisasi mengenai informasi penting terkait pencegahan dan pemberantasan perdagangan perempuan perlu ditingkatkan karena masih banyak masyarakat yang belum mengetahui hakikat perdagangan perempuan. Di samping itu perlu disampaikan hak dan kewajiban bagi pekerja prosedural dan nonprosedural. Sosialisasi dapat dilaksanakan melalui dana desa, diintegrasikan dalam materi-materi ceramah dan pengajian, atau ceramah-ceramah di gereja atau tempat ibadah lainnya, dan dapat dilaksanakan oleh organisasi kemasyarakatan secara mandiri. Sosialisai dapat juga diintegrasikan dengan berbagai program kegiatan, baik ditingkat kecamatan atau desa. Selanjutnya sosialisasi juga dapat dilaksanakan di sekolah-sekolah, baik melalui program sekolah maupun program dinas pendidikan.

Tidak kalah penting juga, perlu adanya administrasi yang tertib tentang data-data penduduk ditingkat desa, sehingga dapat diketahui setiap penduduk yang datang dan pergi ditingkat RT/RW dan apabila ada warga yang keluar tanpa pemberitahuan kepada pengurus RT/RW, maka pengurus harus melakukan konfirmasi ke pihak keluarga dan bahkan dapat melaporkannya pada pihak kepolisian.

Hal lainnya, perlu ada upaya dari pihak pemerintah, baik dari dinas sosial dan tenaga kerja, dinas koperasi usaha kecil menengah dan perdagangan untuk memprogramkan kegiatan pelatihan ekonomi kreatif dalam bentuk pelatihan 
kerajinan tangan, kuliner, dan industri kreatif untuk perempuan. Pemerintah kabupaten juga perlu melakukan kerja sama dengan pihak investor untuk mendirikan pabrik indutri unggulan kearifan lokal daerah agar dapat menekan dan mengurangi tingkat pengangguran khususnya bagi perempuan di desa-desa. Selain itu, aparat kepolisian harus bekerja lebih optimal, baik secara preventif maupun represif. Tindakan Preventif, yaitu melakukan pengawasan bersama TNI secara ketat di tempat lain yang diperkirakan dapat melancarkan lalu lintas perdagangan wanita dan anak seperti pelabuhan laut, b) pelabuhan udara, dan patroli perairan untuk mengawasi tempat-tempat hiburan malam yang diperkirakan sebagat tempat transaksi perdagangan perempuan, (bekerja sama dengan dinas sosial) serta bekerja sama dengan dinas komunikasi dan informasi tentang perdagangan perempuan atau prostitusi online. Tindakan represif yaitu menindak tegas pelaku kejahatan perdagangan perempuan.

Kemudian yang tidak kalah penting adalah membuka tempat pelaporan atau pengaduan (pos terpadu di desa-desa) yang mudah diakses apabila ada hal-hal yang mencurigakan atau terindikasi merupakan tindak pidana perdagangan orang atau trafficking. Terakhir Dinas Imigrasi harus lebih teliti mengeluarkan paspor dan peruntukannya yang disertai data-data yang valid dan akurat untuk mencegah penyalahgunaan paspor.

\section{UCAPAN TERIMA KASIH}

Ucapan terima kasih ini ditujukan kepada semua pihak yang turut terlibat dalam proses riset ini. Terutama bagi Bupati Kabupaten Sambas beserta staf dinas yang menangani kasus-kasus perdagangan orang (perempuan dan anak) di Kabupaten Sambas. Ucapan terima kasih pula untuk kolega-kolega di IAIN Pontianak yang turut memberikan masukan atas tulisan ini.

\section{DAftar Pustaka}

Astuti, T. M. P. (2018). Trafficking di Pos Lintas Batas Entikong-Tebedu: Kasus di Perbatasan Indonesia dengan Malaysia. Forum Ilmu Sosial, 45(1), 34-50. Retrieved from https://journal.unnes.ac.id/nju/index.php/FIS/article/ view/15546/8077

Asyahri, Y., \& Syafril, S. (2018). Pengembangan Kawasan Andalan Provinsi Kalimantan Selatan. Matra Pembaruan, 2(1), 27-38. https://doi. org/10.21787/mp.2.1.2018.27-38

Bintari, A., \& Djustiana, N. (2017). Upaya Penanganan Korban dan Pencegahan Tindak Perdagangan Orang (Human Trafficking) di Kabupaten Indramayu Provinsi Jawa Barat. CosmoGov, 1(1), 124. https://doi.org/10.24198/cosmogov.v1i1.11803
Creswell, J. (2014). Research Design: Qualitative, Quantitative, and Mixed Methods Approaches. 4th Edition. The New Zealand dental journal (Vol. 86). SAGE. https://doi. org/10.4135/9781849208956

Darwinsyah, M. (2011). Strategi Penanganan Trafficking di Indonesia. Kanun: Jurnal Ilmu Hukum, 13(2), 21-31. Retrieved from http://jurnal.unsyiah.ac.id/kanun/article/view/6240

Elyta, E. (2012). Penanggulangan Perdagangan Perempuan di Perbatasan Entikong Kabupaten Sanggau Kalimantan Barat: Perspektif Keamanan Manusia. Indonesian Journal of Dialectics, 2(2), 1-16. Retrieved from http://jurnal. unpad.ac.id/ijad/article/view/2655

Grevisanto, A. F. (2016). Urgensi Eksistensi Wilayah Perbatasan Terhadap Konsep Pertahanan dan Keamanan NKRI. Retrieved October 29, 2019, from https://www.kompasiana.com/argagrevisanto/582ed50622afbda50ad894bf/ urgensi-eksistensi-wilayah-perbatasan-terhadap-konsep-pertahanan-dan-keamanan-nkri?page $=$ all

Irawan, P. (2014). Jurnal komunikasi. Jurnal Komunikasi Untar, 6(3), 59-73. Retrieved from https:// www.neliti.com/id/publications/107643/ internet-dan-fenomena-bangkitnya-peran-aktor-non-negara

Jones, C. O. (2007). An Introduction to The Study of Public Policy (3rd ed.). Michigan: Brooks/Cole Publishing Company.

Judge, S. M., \& Boursaw, B. (2016). The Impact of the Trafficking Victims Protection Act of 2000 on Trends in Federal Sex Trafficking Cases. Criminal Justice Policy Review, 29(8), 823-848. https://doi.org/10.1177/0887403416655430

Kristi, P., Damayanti, C., \& Haqqi, H. (2018). Border Diplomacy Pemerintah Republik Indonesia Dalam Menangani Penyelundupan Gula di Entikong. Transformasi, 1(34), 43-55. Retrieved from https://ejurnal.unisri.ac.id/index.php/ Transformasi/article/view/2744/2455

Laki, J. (2006). Non-Traditional Security Issues: Securitisation of Transnational Crime in Asia (Southeast Asia and ASEAN No. WP098). Singapore. Retrieved from https://www.rsis.edu. sg/rsis-publication/nts/98-wp098-non-traditional-secu/\#.XbZg7NVS-Uk

Muflichah, H. S., \& Bintoro, R. W. (2009). Trafficking: Suatu Studi Tentang Perdagangan Perempuan dari Aspek Sosial, Budaya dan Ekonomi di Kabupaten Banyumas. Jurnal Dinamika Hukum, 9(2), 125-134. https://doi.org/10.20884/1. jdh.2009.9.2.222

Nasution, M. S. (2018). Potensi Wilayah Perbatasan Strategis. Jurnal Kebijakan Publik, 9(2), 117124. Retrieved from https://ejournal.unri. ac.id/index.php/JKP/article/view/7413 
Nel, S. L. (2005). Victims of Human Trafficking: Are They Adequately Protected in the United States? Journal of International and Comparative Law, 5(1), 1-33. Retrieved from https:// scholarship.kentlaw.iit.edu/ckjicl/vol5/iss1/3

Niko, N. (2016). Kemiskinan Sebagai Penyebab Praktik Human Trafficking di Kawasan Perbatasan Jagoi Babang (Indonesia-Malaysia) Kalimantan Barat. In Prosiding Seminar Nasional INDOCOMPAC (pp. 515-524). Jakarta: Universitas Bakrie. Retrieved from http://jurnal. bakrie.ac.id/index.php/INDOCOMPAC/article/ view/1625

Niko, N. (2017). Fenomena Trafficking in Person di Wilayah Perbatasan Kalimantan Barat. Raheema, 4(1), 32-45. https://doi.org/10.24260/ raheema.v4i1.829

Niko, N. (2019). Kemiskinan Perempuan Dayak Benawan di Kalimantan Barat sebagai Bentuk
Kolonialisme Baru. Jurnal Pemikiran Sosiologi, 6(1), 58-76. Retrieved from https://journal. ugm.ac.id/jps/article/view/47467/pdf

Widayatun, W. (2008). Trafficking di Wilayah Perbatasan. Jurnal Masyarakat Dan Budaya, 10(1), 81-102. https://doi.org/10.14203/JMB. V10I1.172

Widiastuti, T. W. (2010). Upaya Pencegahan Tindak Pidana Perdagangan Orang (Trafficking). Wacana Hukum, 9(1), 107-120. Retrieved from https://ejurnal.unisri.ac.id/index.php/Wacana/article/view/308/270

Wulang, A. T., Nawawi, J., \& Nurlinah, N. (2013). Analisis Penerapan Kebijakan Pencegahan dan Penghapusan Perdagangan (Trafficking) Perempuan dan Anak di Kota Makassar. GOVERNMENT : Jurnal Ilmu Pemerintahan, 6(1), 1-20. Retrieved from http://journal.unhas.ac.id/index.php/government/article/view/1258 